Goldschmidt 2021 Abstract

https://doi.org/10.7185/gold2021.7686

\section{First identification, geochemical characterization, and land-sea correlations of Holocene marine distal tephra from the Ecuadorian arc}

\author{
MATHILDE BABLON ${ }^{1,2}$, FRANÇOIS NAURET ${ }^{3}$, PABLO
} SAMANIEGO $^{3,4}$, JEAN-LUC DEVIDAL ${ }^{3}$, GUEORGUI RATZOV $^{2}$, FRANÇOIS MICHAUD ${ }^{2,5}$, MARIANNE SAILLARD $^{2}$, FRANÇOIS ORANGE ${ }^{6}$, JEAN-NOEL PROUST $^{7}$, JEAN-LUC LE PENNEC $^{3,4}$, CÉLINE LIORZOU ${ }^{8}$, SILVIA VALLEJO ${ }^{4}$, PATRICIA MOTHES ${ }^{4}$ AND SILVANA HIDALGO $^{4}$

${ }^{1}$ ISTerre - Université Grenoble Alpes

${ }^{2}$ Université Côte d'Azur, IRD, CNRS, Observatoire de la Côte d'Azur, Géoazur

${ }^{3}$ Laboratoire Magmas et Volcans, Université Clermont Auvergne

${ }^{4}$ Instituto Geofísico, Escuela Politécnica Nacional

${ }^{5}$ Sorbonne Université, Institut des Sciences de la Terre de Paris, Campus Pierre et Marie Curie

${ }^{6}$ Université Côte d'Azur, Centre Commun de Microscopie

Appliquée

${ }^{7}$ Université Rennes 1, Géosciences Rennes

${ }^{8}$ Université de Bretagne Occidentale, Laboratoire Géosciences Océan

Presenting Author: mathilde.bablon@univ-grenoble-alpes.fr

Correlations between marine distal ash layers and continental proximal volcanic deposits constitute a strong tool to investigate the eruptive chronology of an active volcanic arc, to constrain the detailed stratigraphy of the marine sediments, as well as help to constrain the magnitude of some large explosive eruptions.

In the Andean Northern Volcanic Zone (NVZ), Ecuadorian Holocene major explosive eruptions have been widely documented over the past 30 years, and a large geochemical and geochronological database is available. However, the dispersion of distal volcanic products associated with these events is poorly known, and investigation of offshore tephra fallout deposits appears essential to clarify the recurrence, magnitude, and impact of past major explosive eruptions, and thus to better define the volcanic hazards.

We present for the first time chemical and morphological features of 30 Holocene tephra layers sampled in marine cores off the Ecuadorian coast during the Amadeus and Atacames cruises [1-2]. Tephra layers are mainly composed of glass shards visible to the naked eye $(\sim 50-150 \mu \mathrm{m})$ with some calcareous nannofossils, foraminifera and diatoms. We present new geochemical data obtained on these tephra layers and compare different analysis techniques applied on such material. Major and trace element contents were measured on single glass shards by electron microprobe and LA-ICP-MS (Laser Ablation Inductively Coupled Plasma Mass Spectrometry), respectively, and compared to bulk whole-rock measurements performed by ICP-AES (Atomic Emission Spectrometry). $\mathrm{Pb}$ isotopic composition was analyzed by MC-ICP-MS (MultiCollector ICP$\mathrm{MS})$. Comparison of the chemical and isotopic signature of marine tephra with data acquired on land allows us to correlate some historic events, but also highlights eruptions that do not seem to have been described otherwise.

Finally, land-sea correlations of tephra fallout deposits will also provide temporal constraints to marine seismic records, constrain the age of the tectonic structures of the basin, and possibly better define the recurrence of paleoearthquakes in this region where the seismic hazard is particularly high.

[1] Heads of cruise: F. Michaud and J-N. Proust, R/V L'Atalante, 2005

[2] Head of cruise: J-Y. Collot, R/V L'Atalante, 2012 